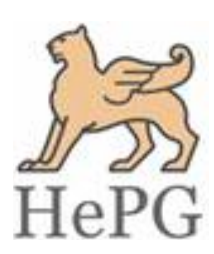

ISSN: 2348-1900

Plant Science Today

http://www.plantsciencetoday.online

OPEN (-) ACCESS

Research Article

\title{
Medicinal plants with preventive and therapeutic effect on diarrhoea: A cross-sectional epidemiologic and ethnobotanical study in traditional therapists of Shahrekord, south-west of Iran
}

\author{
Khatereh Anbari ${ }^{1}$, Saber Abbaszadeh ${ }^{2,3,4}$ \& Gholam Basati $^{5^{*}}$ \\ ${ }^{1}$ Community Medicine Department, Lorestan University of Medical Sciences, Khorramabad, Iran \\ ${ }^{2}$ Student Research Committee, Lorestan University of Medical Sciences, Khorramabad, Iran \\ ${ }^{3}$ Nutritional Health Research Center, Lorestan University of Medical Sciences, Khorramabad, Iran \\ ${ }^{4}$ Hepatitis Research Center, Lorestan University of Medical Sciences, Khorramabad, Iran \\ ${ }^{5}$ Biotechnology and Medicinal Plants Research Center, Ilam University of Medical Sciences, Ilam, Iran
}

\section{Article history}

Received: 17 August 2019

Accepted: 27 August 2019

Published: 13 October 2019

\section{Publisher}

Horizon e-Publishing Group

\author{
*Correspondence \\ Gholam Basati \\ $凶$ gholam basati@yahoo.com
}

\begin{abstract}
Chemical treatments for diarrhoea usually lead to side effects, so humans are seeking out a safe pharmaceutical source to cure them. From ancient times, medicinal plants have served as an important pharmaceutical source for the treatment of various acute and chronic diseases and infectious and non-infectious diseases. This study was carried out from April 2017 to February 2018 by interviewing with and administering a questionnaires to 29 traditional therapists. The questionnaire also included demographic items. The interviewers referred to the participants in person and asked them certain questions to elicit their beliefs about herbal medicine. Data were finally analyzed by the Excel software. In this study, the frequency of plant use was calculated by using a formula. According to the ethnobotanical knowledge of the region under study, Astragalus hamosus L., Ziziphora taurica M.Bieb., Anthemis hyalina DC., Plantago major L., Quercus brantii Lindl., Myrtus communis L., Satureja bachtiarica Bung., Glycyrrhiza glabra L., Peganum harmala L., Rheum ribes L., Rumex pulcher L., Artemisia absinthium, Descurainia sophia (L.) Prantle., Plantago major L. and some others medicinal plants are used as antidiarrhoeal medicinal plants. Most plant species reported belong to the Asteraceae family and the aerial part $(36 \%)$ is the most frequently used plant organ for cases of diarrhoea in Shahrekord. The scientific registration and review of the written and non-written knowledge of different ethnicities in Iran regarding traditional medicine will help preserve the valuable treasure of thousands of years of Iranians' medical knowledge and experience and will provide the basis for the discovery of new drugs and the progress of the pharmaceutical industry.
\end{abstract}

Keywords: Children; Diseases; Preventive; Treatment; Diarrhoea; Shahrekord; Iran

Citation: Anbari K, Abbaszadeh S, Basati G. Medicinal plants with preventive and therapeutic effect on diarrhoea: A cross-sectional epidemiologic and ethnobotanical study in traditional therapists of Shahrekord, south-west of Iran. Plant Science Today 2019;6(4):512-517. https://doi.org/10.14719/pst.2019.6.4.628

Copyright: (C) Anbari et al. (2019). This is an open-access article distributed under the terms of the Creative Commons Attribution License, which permits unrestricted use, distribution, and reproduction in any medium, provided the original author and source are credited (https://creativecommons.org/licenses/by/4.0/).

Indexing: Plant Science Today is covered by Scopus, Web of Science, BIOSIS Previews, ESCI, CAS, AGRIS, CABI, UGC-CARE, Google Scholar, etc. Full list at http://www.plantsciencetoday.online

\section{Introduction}

Diarrhoea remains the leading cause of death in children under the age of five $(1,2)$. The main impact of diarrhoeal diseases is observed in developing countries. Each child develops diarrhoea six or seven times on average each year (3). Diarrhoea-accompanying diseases affect children's health substantially (4). Diarrhoea is one of the ways of the body to kill germs and often lasts 
from a few days to a week; diarrhoea often involves fever, nausea, vomiting, and dehydration. The causes of diarrhoea are usually viral, bacterial or parasitic infections affecting the digestive tract $(5,6)$. Shortage of water and lack of observing health principles, lack of education and personal hygiene, malnutrition and immune disorder due to HIV are major causes of diarrhoeal disease in developing countries (6). About 1.5 to 5 billion cases of diarrhoea occur annually. The disease is more prevalent in developing countries. In these countries, children get diarrhoea on average 5 times a year (4-6).

Several over-the-counter medications can help treat diarrhoea. Medications such as bismuth (Pepto-Bismol), atopolgate (Kaopectate) and loperamide (Imodium) can help reduce the symptoms of diarrhoea without curing the disease $(5,6)$. Chemical treatments for diarrhoea usually lead to side effects, so humans are seeking out a safe pharmaceutical source to cure them. From ancient times, medicinal plants have served as an important pharmaceutical source for the treatment of various acute and chronic diseases and infectious and non-infectious diseases (7-18).

Medicinal herbs are herbs that contain one or more organs containing the active ingredient. Medicinal herbs are used to treat a variety of diseases. They have therapeutic, control and preventive effects. One of the controversial issues regarding medicinal plants is indigenous knowledge. This knowledge is very extensive and includes a variety of aspects, including the ethnobotany of medicinal plants. Ethnobotany refers to the knowledge of human about the botany and ecology of plants. In this ethnobotanical study, the medicinal plants effective on children diarrhoea according to the indigenous knowledge of people in traditional therapists Shahrekord were investigated.

\section{Materials and methods}

Procedure for collecting indigenous knowledge about phytotherapy in Shahrekord

\section{Type of study}

This cross-sectional, ethnobotanical study was done by collecting indigenous knowledge of traditional therapists in Shahrekord (Fig. 1) using a questionnaire to identify medicinal plants in the region with anti-diarrhoeal effects in children. This study was carried out from April 2017 to February 2018 by interviewing with and administering a questionnaire to 29 traditional therapists in Shahrekord.

\section{Area of study}

Shahrekord is the highest city in Iran. Shahrekord is one of the western cities of Iran and is the capital of Chaharmahal and Bakhtiari province. Shahrekord has a population of 169199 people.
The language of the people is Persian and Shahrekord has a temperate semi-humid climate with mild summers and very cold winters. The average annual temperature in the Kurdish city is $1.5^{\circ} \mathrm{C}$, which is four and a half degrees below the global average. The coldest and warmest months of the month are Shahrekord in January and August respectively.

\section{How to gather traditional information and knowledge}

The questionnaires also included demographic information. The interviewers referred to the participants in person and asked them certain questions to elicit their beliefs about herbal medicine. Out of 29 respondents, 8 were female and 21 male. Their education level was from high school diploma to a master degree. The data drawn from the questionnaires were tabulated in the same way. Data were finally analyzed by the Excel software. In this study, the frequency of plant use was calculated by the following formula.

$$
\begin{aligned}
& \text { Number of times } \\
& \text { the plant is used }
\end{aligned}=\frac{\begin{array}{l}
\text { Number of people who have } \\
\text { mentioned the plant effect }
\end{array}}{\begin{array}{l}
\text { total number of people who } \\
\text { filled out questionnaires }
\end{array}} \times 100
$$

\section{Results}

The analysis of data drawn from the questionnaires shows that according to the ethnobotanical knowledge in the region under study, 21 species of medicinal plants including Astragalus hamosus L., Ziziphora taurica M.Bieb., Anthemis hyalina DC., Plantago major L., Quercus brantii Lindl., Myrtus communis L., Satureja bachtiarica Bung., Glycyrrhiza glabra L., Peganum harmala L., Rheum ribes L., Rumex pulcher L., Artemisia absinthium, Descurainia sophia (L.) Prantle., Plantago major L. and some other medicinal plants are used as anti-diarrhoeal medicinal plants. Additional information on antidiarrhoeal medicinal plants is shown in Table 1.

The results of data analysis are shown in Table 1 and are illustrated in Fig. 2 and 3. Most plant species reported $\left(n_{=} 5\right)$ belong to the Asteraceae family and the aerial part (36\%) is the most frequently used plant organ for cases of diarrhoea in Shahrekord (Fig. 2).

\section{Discussion}

Most plant-derived drugs have been obtained through the study of traditional therapies and indigenous knowledge of the ancient tribes, and despite the enormous advances in the synthesis of synthetic compounds, some of these compounds are still irreplaceable (19-23). Ethnobotany deals with the study of the use of plants by the people of a certain tribe or a community and is known as an effective means to draw indigenous knowledge 
Table 1. The scientific name, family, Persian name, used organ(s), and frequency of use of medicinal plants used as antidiarrhoeal agents in Shahrekord

\begin{tabular}{|c|c|c|c|c|c|c|}
\hline Scientific name & Family & Local name & $\begin{array}{c}\text { Frequency of } \\
\text { use }\end{array}$ & $\begin{array}{l}\text { Voucher } \\
\text { specimens }\end{array}$ & $\begin{array}{l}\text { Organs } \\
\text { used }\end{array}$ & Effect \\
\hline Astragalus hamosus L. & Fabaceae & Nakhonak & $6 \%$ & 346 & $\begin{array}{l}\text { Aerial } \\
\text { organs }\end{array}$ & Anti-diarrhoea \\
\hline Ziziphora taurica M.Bieb. & Lamiaceae & kakouti & $6 \%$ & 426 & $\begin{array}{l}\text { Aerial } \\
\text { organs }\end{array}$ & Anti-diarrhoea \\
\hline Anthemis hyalina DC. & Asteraceae & babouneh & $31 \%$ & 238 & Flower & Anti-diarrhoea \\
\hline Plantago major L. & Plantaginaceae & Barhang & $13 \%$ & 328 & $\begin{array}{l}\text { Aerial } \\
\text { organs }\end{array}$ & Anti-diarrhoea \\
\hline Quercus brantii Lindl. & Fagaceae & Balout & $41 \%$ & 135 & Fruit & Anti-diarrhoea \\
\hline Myrtus communis L. & Myrtaceae & Mord & $6 \%$ & 176 & Leaf, stem & Anti-diarrhoea \\
\hline Satureja bachtiarica Bunge & Lamiaceae & Marzeh kouhi & $6 \%$ & 159 & $\begin{array}{l}\text { Aerial } \\
\text { organs }\end{array}$ & Anti-diarrhoea \\
\hline Glycyrrhiza glabra L. & Fabaceae & Shirin bian & $3 \%$ & 171 & Root & Anti-diarrhoea \\
\hline Peganum harmala L. & Zygophyllaceae & Espand & $3 \%$ & 178 & Seed, leaf & Anti-diarrhoea \\
\hline Rheum ribes L. & Polygonaceae & Rivas & $3 \%$ & 130 & Stem, leaf & Anti-diarrhoea \\
\hline Rumex pulcher L. & Polygonaceae & Torshak & $3 \%$ & 95 & $\begin{array}{l}\text { Aerial } \\
\text { organs }\end{array}$ & Anti-diarrhoea \\
\hline Artemisia absinthium L. & Asteraceae & Afsantin & $3 \%$ & 291 & $\begin{array}{l}\text { Aerial } \\
\text { organs }\end{array}$ & Anti-diarrhoea \\
\hline $\begin{array}{l}\text { Descurainia sophia (L.) Webb } \\
\text { ex Prantl }\end{array}$ & Brassicaceae & Khakshir & $6 \%$ & 282 & Seed & Anti-diarrhoea \\
\hline Vitis vinifera $\mathrm{L}$. & Vitaceae & Angour & $3 \%$ & 237 & Leaf, fruit & Anti-diarrhoea \\
\hline Artemisia annua L. & Asteraceae & Dermaneh & $3 \%$ & 413 & $\begin{array}{l}\text { Aerial } \\
\text { organs }\end{array}$ & Anti-diarrhoea \\
\hline Achillea wilhelmsii C. Koch. & Asteraceae & Berenjas & $10 \%$ & 444 & $\begin{array}{l}\text { Aerial } \\
\text { organs }\end{array}$ & Anti-diarrhoea \\
\hline Pistachia atlanta Desf. & Anacardiaceae & Pesteh kouhi & $3 \%$ & 437 & Fruit & Anti-diarrhoea \\
\hline Prangos ferulacea $\mathrm{L}$. & Apiaceae & Jashir & $13 \%$ & 428 & $\begin{array}{l}\text { Leaf, stem, } \\
\text { seed }\end{array}$ & Anti-diarrhoea \\
\hline Plantago major L. & Plantaginaceae & Asfarzeh & $3 \%$ & 456 & $\begin{array}{l}\text { Aerial } \\
\text { organs }\end{array}$ & Anti-diarrhoea \\
\hline Echinophora platyloba DC. & Apiaceae & Khosarizeh & $3 \%$ & 146 & $\begin{array}{l}\text { Aerial } \\
\text { organs }\end{array}$ & Anti-diarrhoea \\
\hline $\begin{array}{l}\text { Tanacetum polycephalum (L.) } \\
\text { Schultz Bip. }\end{array}$ & Asteraceae & Mokhalaseh & $3 \%$ & 111 & Leaf, stem & Anti-diarrhoea \\
\hline
\end{tabular}

about the uses of plants. Over the past decade, the purposeful study of native pharmacopoeias aimed to produce new drugs has been given priority in the agenda of many national and international organizations. The positive approach of scientists and the increased tendency of governments to collaborate with ethnobotanical projects indicates the growing value of the data obtained from these studies. Medicinal herbs and natural and mineral medicinal compounds are used for therapeutic purposes in digestive diseases and diarrhoea (2426). In addition, these medicinal plants used to treat diarrhoea need to be identified correctly, and advanced scanning electron microscopy is recommended (27-31). The scientific registration and review of the written and non-written knowledge of different ethnicities in Iran regarding traditional medicine will help preserve the valuable treasure of thousands of years of Iranians' medical knowledge and experience and will provide the basis for the discovery of new drugs and the progress of the pharmaceutical industry.

The main treatment for diarrhoea involves the supply of water and electrolytes. Some herbs are water-absorbing and help to treat diarrhoea. Medicinal herbs also help treat infectious diarrhoea because of its antimicrobial properties. Also, some herbs have anti-protozoic and antiviral properties and eliminate parasitic and viral agents in diarrhoea. Others have tannins and pectins that 


\section{Iran}

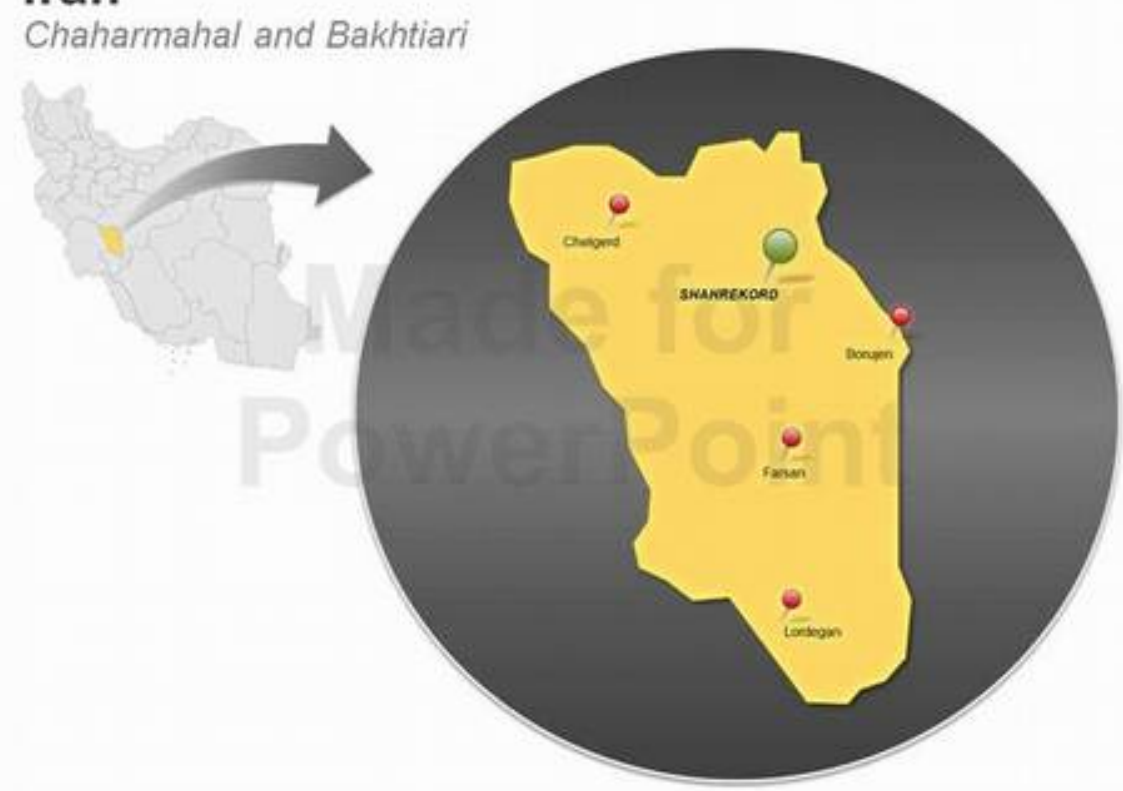

Fig. 1. Map of Shahrekord city

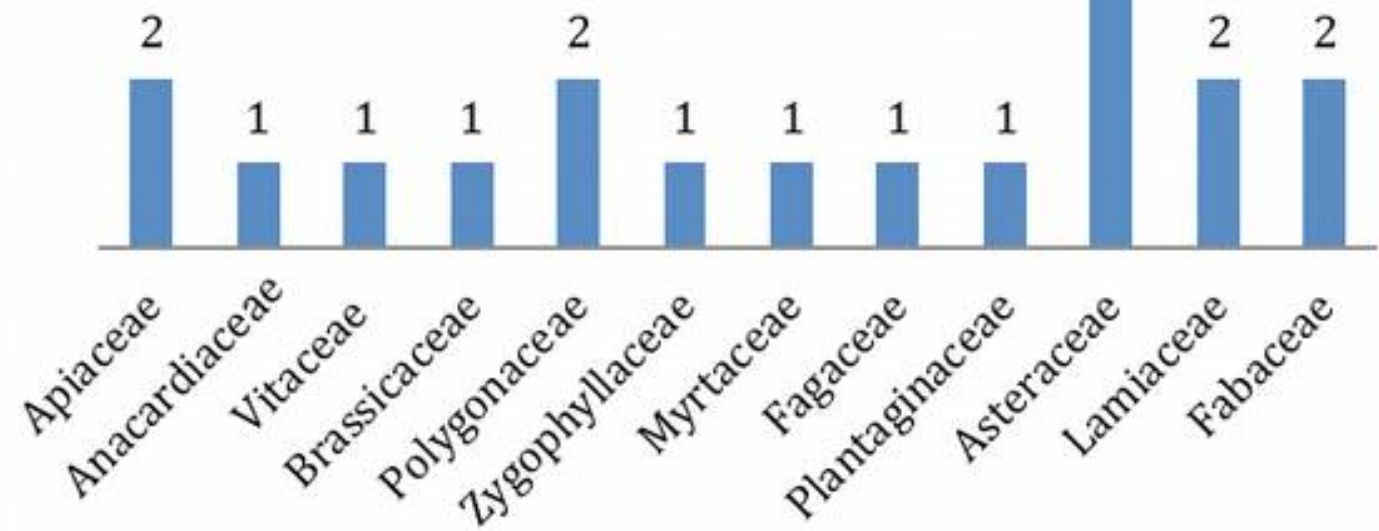

Fig. 2. The distribution of antidiarrhoeal plant families in Shahrekord

help treat diarrhoea. Others also play an important role in improving diarrhoea by strengthening the immune system and increasing the body's level of natural antibodies. Other mechanisms of medicinal herbs to improve diarrhoea are to reduce bowel movement, which, by reducing bowel movement, increases water absorption in the body than before (32-35).

\section{Conclusion}

Based on the ethno-botanical knowledge in the region can be used as anti-diarrhoea. The anti-diarrhoea effects of some of these plants have already been reported. Regarding the difference in the ethnobotany of medicinal plants between the people of Shahrekord and those of other regions across Iran and different uses of different medicinal plants, as well as the availability of certain medicinal plants in the studied area, our findings on the knowledge of the indigenous people in Shahrekord about the use of medicinal plants may be useful. Therefore, if this therapeutic approach is chosen, the side effects of the

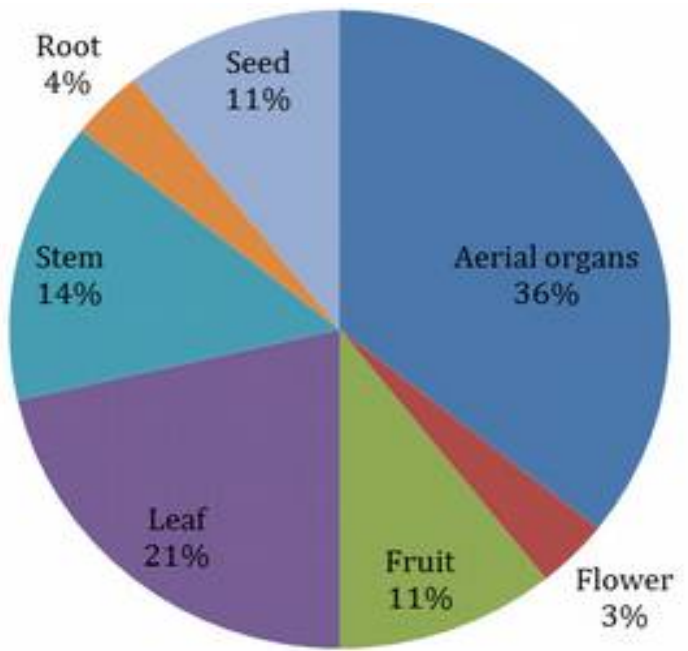

Fig. 3. The percentage of the use of plant organs for their antidiarrhoeal effect in Shahrekord 
plant(s) must be taken into account because medicinal plants are not completely harmless and their efficacy has not yet been definitely approved. Therefore, they should be investigated in well-designed clinical trials.

\section{Conflicts of interest}

The authors declare no conflict of interest.

\section{Acknowledgements}

The authors would like to acknowledge from Lorestan University of Medical Sciences and Ilam University of Medical Sciences for supporting this study.

\section{Authors' contributions}

All the authors contributed equally to the work presented in this paper.

\section{References}

1. Victora CG, Bryce J, Fontaine O, Monasch R. Reducing deaths from diarrhoea through oral rehydration therapy. Bulletin of the World Health Organization 2000; 78 (10): 1246- 55.

2. Kosek M, Bern C, Guerrant RL. The global burden of diarrhoeal disease, as estimated from studies published between 1992 and 2000. Bulletin of the World Health Organization 2003; 81 (3): 19- 204.

3. Santosham M, Keenan EM, Tulloch J, Broun D, Glass R. Oral rehydration therapy for diarrhoea: an example of reverse transfer of technology. Pediatrics 1997; 100(5): 10. https://doi.org/10.1542/peds.100.5.e10

4. Snyder JD, Merson MH. The magnitude of the global problem of acute diarrhoeal disease: a review of active surveillance data. Bulletin of the World Health Organization 1982; 60 (4): 605-13.

5. Cheng AC, Ferguson JK, Richards MJ, Robson JM, Gilbert GL, McGregor A, Roberts S, Korman TM, Riley TV. Australasian Society for Infectious Diseases guidelines for the diagnosis and treatment of Clostridium difficile infection. Med J Aust. 2011;194: 353-58.

6. Zimmerman CM, Bresee JS, Parashar UD, Riggs TL, Holman RC, Glass RI. Cost of diarrhoea associated hospitalizations and outpatient visits in an insured population of young children in the United States. Pediatr Infect Dis J. 2001; 20: 14-19. https://doi.org/10.1097/00006454-200101000-00004

7. Ghanadi K, Hasanvand A, Abbaszadeh S, HeidariSoureshjani S, Suhan T. Phytotherapy: An antihepatotoxicity and hepatoprotective approach in chemotherapy. Plant Sci Today. 2019;6(2):114-22. https:// doi.org/10.14719/pst.2019.6.2.514

8. Anbari K, Hasanvand A, Andevari AN, Abbaszadeh S. Concise overview: A review on natural antioxidants and important herbal plants on gastrointestinal System. Res J Pharm Technol. 2019;12(2):841-47. https://doi.org/10.5958/0974-360X.2019.00145.8

9. Kheirollahi A, Hasanvand A, Abbaszadeh S, Moghadasi M. Pathophysiology and Urinary System Cancer: An Overview of the most important Herbal Plants and Natural Antioxidants on Kidney and Bladder Disorders. Res J Pharm Technol. 2019;12(2):972-80. https://doi.org/10.5958/0974-360X.2019.00161.6
10. 10. Nejad ASM, Bahmani M, Shah NA, Shah SA, RafieianKopaei M. Beliefs of herbal therapies of the community of the Ilam city of Ilam province, Iran. J Pharmacy Pharmacog Res 2018; 6(4): 299-317.

11. Rafieian-kopaei M, Shakiba A, Sedighi M, Bahmani M. The Analgesic and Anti-Inflammatory Activity of Linum usitatissimum in Balb/c Mice. J Evidence-Based Complemen Altern Med 2017; 22(4): 892-96. https://doi.org/10.1177/2156587217717416

12. Froushani SMA, Zarei L, Ghaleh HEG, Motlagh BM. Estragole and methyl-eugenol-free extract of Artemisia dracunculus possesses immunomodulatory effects. Avicenna J Phytomed 2016; 6(5): 526-34.

13. Abbasi N, Azizi Jalilian F, Abdi M, Saifmanesh M. A comparative study of the antimicrobial effect of Scrophularia striata Boiss. Extract and selective antibiotics against Staphylococcus aureus and Pesudomonas aeruginosa. J Med Plants. 2007;6(1): 1018,69 .

14. Bahmani M, Khaksarian M, Rafieian-Kopaei M, Abbasi N. Overview of the therapeutic effects of Origanum vulgare and hypericum perforatum based on Iran's ethnopharmacological documents. J Clin Diagn Res. 2018;12:1-4. https://doi.org/10.7860/JCDR/2018/34177.11728

15. Shokri Z, Khoshbin M, Koohpayeh A, Abbasi N, Bahmani F, Rafieian-Kopaei, M, Beyranvand F. Thyroid diseases: Pathophysiology and new hopes in treatment with medicinal plants and natural antioxidants. Int J Green Pharmacy. 2018; 12(3): 473-82.

16. Abbasi N, Mohammadpour S, Karimi E, Aidy A, Karimi P, Azizi M, Asadollahi K. Protective effects of smyrnium cordifolium boiss essential oil on pentylenetetrazolinduced seizures in mice: Involvement of benzodiazepine and opioid antagonists. J Biolog Regul Homeos Agents. 2017; 31(3):683-89.

17. Tajbakhsh M, Karimi A, Tohidpour A, Abbasi N, Fallah F, Akhavan MM.The antimicrobial potential of a new derivative of cathelicidin from Bungarus fasciatus against methicillin-resistant Staphylococcus aureus. J Microbiol. 2018; 56(2):128-137. https://doi.org/10.1007/s12275-018-7444-5

18. Bahmani M, Taherikalani M, Khaksarian M, RafieianKopaei M, Ashrafi B, Nazer M et al., The synergistic effect of hydroalcoholic extracts of Origanum vulgare, Hypericum perforatum and their active components carvacrol and hypericin against Staphylococcus aureus. Future Sci OA. 2019; 31;5(3):FSO371. doi: 10.4155/fsoa2018-0096. eCollection 2019 Mar. https://doi.org/10.4155/fsoa-2018-0096

19. David M, Ain Qu, Ahmad M, Zaman W, Jahan S. 2019. A biochemical and histological approach to study antifertility effects of methanol leaf extract of Asplenium dalhousiae Hook. in adult male rats. Andrologia 51, e13262. https://doi.org/10.1111/and.13262

20. Zaman W, Shah SN, Ullah F, Ayaz A, Ahmad M, Ali A. Systematic approach to the correct identification of Asplenium dalhousiae (Aspleniaceae) with their medicinal uses. Microsc Res Tech. 2019; 82, 459-65. https://doi.org10.1002/jemt.23189

21. Zeb S, Ali A, Zaman W, Zeb S, Ali S, Ullah F, Shakoor A. Pharmacology, Taxonomy and Phytochemistry of the genus Artemisia specifically from Pakistan: a comprehensive review. Pharmaceut. Biomed. Res. 2017; 1-10. https://doi.org10.18502/pbr.v4i4.543

22. Ullah F, Shah SN, Zaman W, Ali C, Gul S, Saqib S, Ali A. Traditional knowledge of medicinal herbs among indigenous communities in Maidan Valley, Lower Dir, Pakistan. Bull Env Pharmacol Life Sci. 2018; 7: 1-23. 
23. Zaman W, M. Ahmad M, Zafar H, Amina Lubna F. Ullah S. Bahadur A. Ayaz S, Saqib N, Begum S, Jahan S. The quest for some novel antifertility herbals used as male contraceptives in district Shangla, Pakistan. Acta Ecolog Sinica.

2019;1-11. https://doi.org/10.1016/j.chnaes.2019.05.017

24. Anbari K, Firouzi M, Abbaszadeh S. Probiotics and gastrointestinal diseases: A promising complementary medicine resource for treatment of gastrointestinal disorders and diseases. J Pharmacy Pharmacog Res. 2019; 7(3): 193-99.

25. Nazer MR, Abbaszadeh S, Anbari K, Shams M. A review of the most important medicinal herbs affecting giardiasis. J HerbMed Pharmacol. 2019; 8(2): 78-84. https://doi.org/10.15171/jhp.2019.13

26. Anbari KH, Hasanvand A, Nosrati Andevari A, Moghadasi M, Abbaszadeh S. Concise overview: A review on natural antioxidants and important herbal plants on gastrointestinal System. Res J Pharm Technol. 2019; $\quad 12(2): \quad$ https://doi.org/10.5958/0974360X.2019.00145.8

27. Ashfaq S, Ahmad M, Zafar M, Sultana S, Bahadur S, Ullah F, Zaman W, Ahmed SN, Nazish M. Foliar micromorphology of Convolvulaceous species with special emphasis on trichome diversity from the arid zone of Pakistan. Flora: Morphology, Distribution, Funct Ecol Plants. 2019; 255: 110-24 https://doi.org/10.1016/j.flora.2019.04.007

28. Attar F, Esfandani-Bozchaloyi S, Mirtadzadini M, Ullah F, Zaman W. Foliar and stem epidermal anatomy of the tribe Cynoglosseae (Boraginaceae) and their taxonomic significance. Microsc Res Tech. 2019; 82: 786-802. https:// doi.org/10.1002/jemt.23223

29. 29. Gul S, Ahmad M, Zafar M, Bahadur S, Celep F, Sultana S, Ayaz A. Taxonomic significance of foliar epidermal morphology in Lamiaceae from Pakistan. Microsc Res Tech. 2019; 1-22. https://doi.org10.1002/jemt.23316

30. Esfandani-Bozchaloyi S, Zaman W, Taxonomic significance of macro and micro-morphology of Geranium L. species Using Scanning Electron Microscopy. Microsc Res Tech. 2018; 81: 1520-32. https://doi.org/10.1002/jemt.23159

31. Ullah F, Nasar Shah S, Zaman W, Zafar M, Ahmad M, Ayaz A, Sohail A, Saqib S. Using palynomorphological characteristics for the identification of species of Alsinoideae (Caryophyllaceae): a systematic approach. Grana. 2019; 58: 174-84 https://doi.org/10.1080/00173134.2019.1569719

32. 32. Mengistu G, Engidawork E, Nedi T. Evaluation of the antidiarrhoeal activity of $80 \%$ methanol extract and solvent fractions of the leaves of Lantana camara linn (Verbenaceae) in mice. Ethio Pharm J. 2015; 31: 107-21. https://doi.org/10.4314/epj.v31i2.3

33. Kirimuhuzya C, Waako P, Joloba M, Odeyek O. The antimycobacterial activity of Lantana camara a plant traditionally used to treat symptoms of tuberculosis in South-western Uganda. Afri Health Sci. 2009; 9:40-45.

34. Ghodake PP, Kulkarni AS, Aloorkar NH, Osmani RA, Bhosale RR, Harkare BR, et al. In-vitro Antispasmodic Activity Analysis of Methanolic Leaves Extract of Lantana camara Linn. on Excised Rat Ileum. J Pharmacogn Phytochem. 2013; 2(3):66-71.

35. Bakare RI, Magbagbeola OA, Akinwande AI, Okunowo OW, Green M. Antidiarrhoeal activity of aqueous leaf extract of Momordica charantia in rats J. Pharmacogn Phytother. 2011; 3(1):1-7. 